\title{
The Moderating Effect of Role Ambiguity on the Relationship of Job Satisfaction, Training and Leadership with Employee Performance
}

\author{
Waleed Bin Rashed Alshery ${ }^{1}$, Fais Bin Ahmad ${ }^{1}$ \& Abdullah Kaid Al-Swidi ${ }^{2}$ \\ ${ }^{1}$ School of Business Management, University Utara Malaysia, Sintok, Kedah, Malaysia \\ ${ }^{2}$ College of Business and Economics, Qatar University, Al Doha, Qatar \\ Correspondence: Waleed Bin Rashed Alshery, School of Business Management, University Utara Malaysia, Sintok, \\ Kedah, Malaysia. Tel: 966-5-5546-0052. E-mail: 1bec@live.com
}

Received: January 20, 2015

Accepted: February 3, 2015

Online Published: February 20, 2015

doi:10.5430/ijba.v6n2p30

URL: http://dx.doi.org/10.5430/ijba.v6n2p30

\begin{abstract}
People performance in any organization is the key factor of succeeding the organization with regardless of nature business. The higher education sector of any country is considered one of the sectors which really pay attention on achieving their goals successfully. The numerous difficulties that employees need to face because of the dynamism of working environment had brought about troubles for employees to keep up their job performance. Employees are considered the most imperative element that determines the success of an organization. Thus, this research focus on the factors those positively affect the employees' performance through job satisfaction, leadership and training by taking role ambiguity as a moderating variable in the in higher education of KSA.
\end{abstract}

Keywords: employees' performance, job satisfaction, leadership, training, role ambiguity

\section{Introduction}

The numerous difficulties that employees need to face because of the dynamism of working environment had brought about troubles for workers to keep up their job performance. Actually, employees have a tendency to have elevated expectations concerning workers' job performance by consistently checking their job performance through different performance management exercises (Dessler, 2011). People performance in any organization is the key factor of succeeding the organization with regardless of nature business. The higher education sector of any country is considered one of the sectors which really pay attention on achieving their goals successfully. There are different issues talked about extending from recognizing problems confronted by higher education (HE) in (Kingdom of Saudi Arabia) KSA on issues of benefit and aptitudes deficiencies (Abdullah et al., 2009).

Employees are considered the most imperative element that determines the success of an organization. Furthermore it's worth noting that if employees of an organization are managed properly and give them the sense of comfort they can go beyond the limits to perform for the organization and can directly add into the productivity and efficiency and can reduce the counterproductive behavior in the organization (Fiorita, Bozeman, Young \& Meurs, 2007).

Today's Saudi Arabia is struggling hard to achieve some new targets and benchmarks to make its own identity in the global market. The organizations in all over the world which are on the path to achieve their strategic goals have a comparative low rate of employee turnover and along with this they usually have more competent and satisfied employees with more commitment level. Oganizations in Saudi Arabia including education sector are more concern about the job performance of their employees as it results in the organizational development (Al-Kahtani, 2002). An employee who is well satisfied with his job will definitely perform more for the organization and can go extra miles for the betterment of the organization. Thus, this is very important to understand the factors that affect an employee's job performance including job satisfaction and leader's role (Awang, Ahmad \& Zin, 2010).

Academic staff members' job satisfaction, which considered as the corner stone of the story to push forward the efforts of Universities' authorities to improve employees' performance and to ensure high quality of education to serve both local and national society (Eldin, 2012). Leadership style is one of the ways to establish the realization of objectives in the organization by the influence of managers towards the followers to create motivation which leads to high performance (Salmani \& Taatian, 2010). On the other hand Abdalla and Al-Homoud, (1995) argued that training is not taken as a serious factor in Arab organizations to improve the employees' job performance and is not 
considered as the strategic tool to achieve the organizational goals and same is the case of higher education. Academia is the field which is required proper training to be on job and the public universities of KSA are not exemptions. Universities are well thought-out as the source of knowledge generation and learning and transforming it. So, Universities play an important role in the development of the economy and culture of any country. To perform this vital role Universities are in need to hire skillful and knowledgeable academicians than to retain them and train them to increase their job performance to perform their duties (Khalid, 2012).

According to the literature there are numerous reasons of job stress. Multiple roles and role ambiguity is also considered as the stressor. Employees in organizations are subjected to clash, and the effect of clash is unavoidable, either positive or negative and it at last impacts the organizational performance of workers (Jehn, 1997). Moreover, studies on employee job performance concerning role ambiguity (Bhuian, Menguc \& Borsboom, 2005; Lang, Thomas, Bliese \& Adler, 2007), competency (Vakola, Soderquist \& Prastacos, 2007; Vathanophas \& Thaingam, 2007; Hashim, 2008; Potluri \& Zeleke, 2009) were mostly conducted abroad, and thus lack of evidence exists in KSA to understand the job performance of employees especially those in the education sector. Therefore, organizations must focus on the factors that positively affect the performance of the employees and in turn favorable job attitudes would lead the employees to show the desired behaviors (Altrasi, 2014).

Although there has been prior research regarding the employees' performance, very little research has concentrated on role ambiguity for employees' performance. Existing researches consider on the employees' performance without studying the role ambiguity as moderating. This paper aims to fill this gap in the research literature by focusing on the factors that positively affect the employees' performance through job satisfaction, leadership and training by taking role ambiguity as a moderating variable in the in higher education of KSA.

\section{Literature Review}

\subsection{Employee Performance}

Employee performance is always considered as one of the important factors of employee management. Job performance is generally associated with the competency of employee to perform the tasks and duties assigned to him to achieve the certain targets and goals according to the set standards and patterns or the benchmarks set by the organization (Eysenck, 1998; Mathis \& Jackson, 2000; Bohlander, Snell \& Sherman, 2001).

As cited in Winarno (2008), Dharma (2003) defined the performance as "something that is done or the products or services produced or provided by a person or group of people". Formerly, the research further elaborates that the job performance can also be defined as a result that can be attained by an individual while performing his task. Finally all the results will be judged and evaluated by the manager or any other competent authority. Besides the words by the supervisor or manager or any other competent authority of the organization will be considered as the feedback about the job performance of the employee. Shahzad et. al., (2010) defines performance as a result or magnitude of a commotion for a particular time of period. Job performance can also be defined as a track record of the results achieved from the various types of functions of a particular job or commotion during a particular period of time (Bernardin \& Russel, 2006).

In the same vein, Mayer (2000) defined job performance as "the result of work that can be achieved by a person or group of people in a company suitable with the authority and responsibility in their respective efforts to achieve company goals legally and not violate the law and not contrary to morals or ethics". However, Mackin (2006) defines job performance as an extent to which a person carries out its assigned role by considering the explicit set standards that established by the organization.

Summing up, performance is a distinguishing feature appearance that an employee tries to achieve and should have to attain the particular objectives. The set standards and bench marks should also be well considered while achieving the specific goals. There are many different ways to measure the team performance. Though many researchers have defined the performance in their own words and by taking different variables but the one common thing which is repeated by almost all the researchers is the result that is achieved.

\subsubsection{Models of Job Performance}

A few authors came up with various theories and models on job performance. Each theory and model relates to different situations. This section highlights a few theories on job performance and hence, adapts a reference model for the study conducted. Two major categories of job performance can be found across models: in-role (task) performance and extra-role (contextual) performance (Borman \& Motowidlo, 1993; Conway, 1999). In-role performance refers to performance on the technical aspects of an employee's job where as extra-role performance 
refers to nontechnical abilities such as being able to communicate effectively, shows high motivation level and enthusiasm at work, or be a good team member (Jex \& Britt, 2008).

Murphy, Baker and Gibbons (1994) proposed the second model of job performance. Even though the model was specifically developed to facilitate an understanding of job performance in the U.S. Navy, the performance dimensions are also relevant to any regular jobs. Compared to the first model, this model breaks performance down into four dimensions. The characteristics of the model are summarized in Table 1.

Table 1. Murphy's (1994) model of job performance according to the in-role and extra-role distinction

\begin{tabular}{lll}
\hline No & Performance Dimensions & Descriptions of Performance Dimensions \\
\hline \multicolumn{2}{l}{ In-Role } & Performing major tasks associated with the job \\
1 & Task-Oriented Behaviours & \\
& Extra-Role & All interpersonal transactions that occur on job \\
2 & Interpersonally Oriented Behaviours & $\begin{array}{l}\text { Behaviours outside of work that affect job performance } \\
\text { (drug, use of alcohol, extra jobs) }\end{array}$ \\
4 & Down-time Behaviours & Safety violations, sabotage, accidents
\end{tabular}

Campbell $(1990,1994)$ came up with a comprehensive model of job performance after analysing a diverse set of jobs performed by soldiers in the U.S. Army. The model elaborates that performance on all jobs can be broken down into eight dimensions. Table 2 shows Campbell's (1990, 1994) Model of Job Performance according to the in-role and extra-role distinction. Campbell's in-role was also known as task-performance. From the eight dimensions given in the model, it is well understood that not all of these dimensions would be relevant for all jobs. In fact, only three (Job-Specific-Task Proficiency (core task proficiency), demonstrating effort, and maintenance of personal discipline) were identified as major performance components for all jobs (Campbell, 1990).

Table 2. Campbell's $(1990,1994)$ model of job performance according to the in-role and extra-role distinction

\begin{tabular}{|c|c|c|}
\hline No & Performance Dimensions & Descriptions of Performance Dimensions \\
\hline \multicolumn{3}{|c|}{ In-Role } \\
\hline 1 & Job-Specific-Task Proficiency & Technical aspects of job performance \\
\hline 2 & Non-Job-Specific-Task Proficiency & Common tasks performed by different employees \\
\hline \multicolumn{3}{|c|}{ Extra-Role } \\
\hline 3 & Written and Oral Communication & Ability to write and communicate effectively \\
\hline 4 & Demonstrating Effort & Going the "extra mile" at work \\
\hline 5 & Maintaining Personal Discipline & $\begin{array}{l}\text { Refraining from negative behaviours, following through } \\
\text { on tasks }\end{array}$ \\
\hline 6 & Providing assistance to the team & $\begin{array}{l}\text { Being a good team member, working well with other } \\
\text { members }\end{array}$ \\
\hline 7 & Supervision/Leadership & Effectively supervising and leading others \\
\hline 8 & Management/Administration & $\begin{array}{l}\text { Effectively organising and keeping track of critical } \\
\text { information }\end{array}$ \\
\hline
\end{tabular}

According to Jex and Britt (2008), the Murphy's (1994) four-dimension model was considered less useful compared to Campbell's $(1990,1994)$ eight-dimension model, because the model was developed to explain job performance for the U.S. Navy personnel; whereas, Campbell's objective was to describe performance in a broader term of jobs. Apart from that, Murphy's model was so broad that it was difficult to determine the factors that led to differences among employees on the performance dimensions.

In the perspective of job performance models, the integration of the models summarizes into a specific existence of in-role or task performance that portrays the main tasks or technical aspects of a job that were examined and evaluated during job performance evaluation. Hence, this study only considers task performance dimension of job performance in measuring job performance of academicians. 


\subsubsection{Job Performance among Academicians}

Job performance is an important outcome for any of the academician belongs to the education field. Research pertaining to job performance among academicians has been a popular subject of discussions among the higher education literatures. In the case of Malaysian public universities, job performance reflects the quality of the academicians. Errors can be increased, credibility can be at stake and legalities can be raised due to the poor performance (Fisher, 2001). Studies have been conducted involving significant variables in the behaviour of job performance among academicians. Razali (2011) for example, conducted a study on the effect of work and family on work performance of university lecturers. The respondents were academicians of University Putra Malaysia, Serdang. The research found that there was a significant relationship between the respondents' perceived effect of work and family on work performance. It implies that work and family affect job performance of academicians.

On the other hand, observed the job motivation and job performance in the recipients for outstanding services in the field of Higher Education Institutions. The study depicted that there was no correlation between job motivation and job performance of academicians. In terms of gender influence on emotional self-regulations of academicians in Malaysia, Haryani, (2010) gave an insight of how successful academicians self-regulate their emotions in facing challenges in a new academic norm. It was also found that academicians self-regulate their emotions by motivating own self and staying focus to achieve personal target.

David, Syed, Zaini and Nilufar (2009) explained the job stress and job satisfaction among the staff of Universities in Malaysia. They revealed that if Universities will not provide the healthy working environment which does not have workplace stress, role ambiguity and bullying etc. the employees will not be satisfied and it will be resulted in the low performance of employees. Job performance is indeed a very important aspect for academicians in universities. Roshidi (2005) in his research studied the perceptions of academicians on performance appraisal in public universities and job performance of academicians in Business Management faculties in Malaysian public universities were positively related to healthy workplace (Nanthini, 2007). In addition, appraisal and expression of emotion were found to be moderately correlated to job performance among the academicians.

\subsection{Job Satisfaction}

Job satisfaction and employee's performance are highly interlinked variables. Job satisfaction is an evaluative judgment about the level of delight an employee gets from his or her employment that comprises of both emotional and cognitive components (Hulin \& judge, 2003). The relationship between job satisfaction and occupation performance has intrigued specialists for decades and a few hypothetical clarifications have been placed to clarify this relationship (Schleicher, Watt, \& greguras, 2004). For example, social cognitive speculations foresee that:(a) state of mind around the occupation (e-g. work fulfillment) ought to impact practices on the work (b) practices at work (or the prizes product by performance) lead to the arrangement of state of mind at the occupation and (c) job satisfaction and employment satisfaction are correspondingly related.

In view of examination did by Hawthorne studies, further research to demonstrate that "glad employees are profitable" was done, which has been demonstrated negative. In view of the finish of Hawthorne studies, administrators started their endeavors to make their representatives more content by enhancing work conditions (Icondalkar, 2007), giving sort of administration, stretching different offices to the employees, however it has been discovered that there is no immediate relationship between gainfulness and bliss. Robins inferred that beneficial specialists are liable to be upbeat employees. Further research on the subject recommends that association having upbeat specialists may have expanded benefit.

On individual level, it may not be valid because of multifaceted nature of environment, work forms, different frameworks and sub frameworks having effect on the individual representative. However, it can be said from authoritative perspective that association that have the capacity, develop such arrangements that make workers glad bound to have enhanced gainfulness. Benefit is considered as prize for diligent work, which is because of abnormal state of fulfillment. However, globalization, rate of machines and learning blast, effect of media on specialists, social mindfulness and exclusive requirements of workers to meet social commitments are vital variables to guarantee high fulfillment level of representatives. While developing mechanical practices, above elements ought to be considered positively and worker development accomplished so associations become naturally (Kondalkar, 2007).

Job satisfaction is considered as one of the determinants of job performance and many researchers showed a positive relationship of job satisfaction and job performance (Hakeern, 2008). As researchers defined that job performance is an emotional state of mind which employee actually perceives many features about his job and its features. It is a known fact that satisfied employees bring more customers (Ahmed et al., 2010). 
It is widely observed that job satisfaction is a variable of great interest among the researchers. Employees' involvement in their work and their loyalty to the organization is very important for the development of the organization and job satisfaction is the best tool to make them motivated to achieve the organizational goals. So, job satisfaction and job performance go side by side (Armstrong, 2009). Therefore, the first hypothesis can specified as following:

\section{$H_{1}:$ There is a significant impact of job satisfaction on performance of employees working in public universities of KSA.}

\subsection{Leadership}

To date, the evolution of leadership continues to be a focus and has received significant research attention. There are many ways to define leadership. Based on 54 experts from 38 countries, leadership is about influencing, motivating, and enabling others in their workplace to contribute toward the effectiveness and success of the organizations (McShane \& Glinow, 2010). Leadership is also defined by Robbins and Judge (2007) as the ability of influencing a group toward the achievement of a vision or set of goals. Consequently, a simpler definition was given by (Kassim \& Sulaiman, 2011) as "to be part of management that involves the supervision of others". Cited Pater (2001) in the study of Yang (2010), safety leadership was highlighted as a sub-system of organizational leadership. Lu and Yang (2010) also quoted Wu et al. (2007) for a definition of safety leadership as "the process of interaction between leaders and followers, through which leaders can exert their influence on followers to achieve organizational goals under the circumstances of organizational and individual factors."

According to the writers above, Leadership as an activity or process comes from individual behavior towards followers to enhance the enthusiasm and aspiration to achieve the target and accomplish the objectives. Leadership is the ability of any group to influence them achieving the goals. So leadership can be defined as:

Similarly, the leadership is about exchanged relationship between leaders and subordinates, moreover, it is how leaders influence the followers in establishing the vision, values and the creation of the environment so the objectives can be completed. Leaders should convince of the staff through the consultation, negotiation and compromise to build the confidence among them so that they can influence the employee performance to achieve the goals and gains due to the high performance of the organizations. The leader today aims to understand how their leadership styles can affect the motivation level and ultimately the delivery of business performance.

According to Zaccaro and Klimostki (2002), leadership in the firms these days is becoming a tough business. Today leaders faced lots of significant challenges in their roles and the global changes around them have increased in complexity. Stogdill (1957) defined leadership as individual behavior that guides a group to achieve the common target. Lee and Chuang (2009) emphasized that the excellent leader not only inspires subordinate's potential to enhance efficiency but also to meet their requirements in the process of achieving organizational goals. In line with that, leadership is remarkable as the main factor in enhancing the organizational performance and successfully meets the objectives. It can be understood that there is a strong link between leadership styles and high organizational performance (Santora et al., 1999; Venkataraman, 1997). Further studies suggested that effective leadership behaviors can facilitate the improvement of performance when organizations face these new challenges (McGrath \& MacMillan, 2000; Teece, Pisano \& Shuen, (1997). "Even though, organizational performance refers to the ability of an enterprise to achieve such objectives as high profit, quality product, large market share, good financial results, and survival at pre-determined time using relevant strategy for action" (Koontz \& Donnell, 1993. p, 45).

For better organizational performance which aims to achieve the target and use survival strategies that could be more practical; all that are need the right and effective leadership style (Rowe, 2001). Furthermore, the performance of the organization can also be used to see how the company gets along in the level of benefits, a piece of the entire industry and the issue of quality in relation to the different companies in the same industry. Therefore, it is part of the project of printing gain measured in terms of income, good, growth, partnerships and expansion improvement. Understanding the impacts of authority on performance is the most vital element in light of the fact that initiative is seen by different masters as one of the key main impetuses for an enhancing association's performance. Besides, successful initiative is seen as an intense wellspring of administration advancement and maintained focal point for authoritative performance change (Avolio, 1999; Lado, Boyd \& Wright, 1992; Rowe, 2001).

According to Robbins and Judge (2009) the leader should be both transformational and transactional and pay attention to the concern of the development needs of individual followers so they are changing follower's awareness of the problems by putting them at ease level and to make possible to resolve the issues in an innovative way. Moreover, they should be capable to make employees motivated to achieve the organizational goals by making them 
excited and by putting organizational citizenship behavior in them. Virtually all theoretical treatments of transformational leadership claim that, among its more direct effects, are employee performance and commitment leading to the kind of extra effort required for significant organizational change (Yukl, 1989).

It's a proved fact that the motivated and kind leadership always bring the motivation in the employees to work hard towards achieving the organizational goals (Robbins, Judge, Millett \& Waters-Marsh, 2008). The healthy relationship between the leadership and the employees can make employees to work beyond their organizational obligations and show an organizational citizenship behavior (Robbins \& Judge, 2009).

There is a correlation between the employees' job performance and transformational leadership style (Bass, 1985). This is also notable that the correlation between transformational leadership and employees' job performance is comparatively high as compare to the correlation between the transactional leadership style and employees' job performance (Salmani, 2010). Basically employees perform well when they feel an attachment with organization and these identifications comes with the appreciation by the leaders and once they get the identification it becomes even easier for the organization to make them follow the organizational norms and values which actually gets converted into employees' performance and eventually the organizational performance (Bass, 1985). Therefore, the second hypothesis can specified as following:

\section{$\mathrm{H}_{2}$ : There is a significant impact of leadership style on performance of employees working in the public universities of KSA.}

\subsection{Training}

The extensive literature suggests that the training is an organized process to enhance the employee's knowledge, competency and skills which are important to attain some job specific tasks. Training creates an impact on the organizational competency and volume of revenue the way it affects the employee's competency (Elnaga, 2013).

Preparing is fundamental to build profit as well as to inspire and motivate specialists by telling them how vital their employments are and providing for all of them the data they have to perform those occupations (Anonymous, 1998). The general advantages got from worker preparing are: expanded occupation fulfillment and spirit, expanded inspiration, expanded efficiencies in techniques, bringing about monetary profit, expanded ability to receive new advances and routines, build innovation in methods and items and decreased employee turnover.

According to Hawthorne studies, and various other investigation wear down advantage of worker highlighted the truth that employees who are satisfied by their occupation will have higher occupation execution, and in this way transcendent vocation support, than those who are not content with their occupations (Landy, 1985). Likewise, it is communicated that delegates are more likely to turnover in case they are not satisfied and consequently de motivated to show incredible execution. Laborer execution is higher in energetic and satisfied experts and the organization feels that it easy to awaken high performers to achieve firm targets (Kinicki \& Kreitner, 2007). The delegate could be recently satisfied when they feel themselves ready perform their occupations, which is achieved through better planning undertakings.

Past explores demonstrated a positive connection in the middle of training and employee performance, as training brings advantages for the worker alongside for the firm by absolutely affecting worker performance through the improvement of worker's abilities and conduct. A firm that concentrates on shareholders and client fulfillment understood the significance of putting resources into training, and subsequently perceives the value of employee improvement (Elnaga, 2013).

The organizational mechanism and market demands are changing rapidly so in this changing environment organizations really need to adopt the rapid changes and to respond them timely and efficiently (Tai, 2006). He further mentions that the employers need to train their employees and to equip them with new and advanced skills and working tools to manage rapid changes and to improve their capabilities. An effective training program can benefit the organization in various ways including the increased productivity of employees change (Lu, Tjosvold \& Kan Shi, 2010). Additionally, it also increases the job retention rate among employees as they feel that organization is investing on them which are of mutual benefit of them and the organization by increasing their capabilities and translating that into increased and more efficient employees' performance.

It is noted that the effective training programs enhance the motivation level of the employees. That is the reason that the training programs are considered one of the tools to increase the employees' job performance to achieve the organizational goals. As training refers to improve the existing performance and elevate it to the standardized benchmark. So trainings in a way not only improve the personal capabilities of employees but also make the best use 
of human resource of the organization (Kinicki \& Kreitner, 2007). Therefore, the third hypothesis can be specified as following:

$H_{3}$ : There is a significant impact of training on performance of employees working in the public universities of KSA.

\subsection{Role Ambiguity}

Role ambiguity is defined as the lack of a clear set of instructions for guiding one's actions in a particular setting or to reach a specific goal (Eys \& Carron, 2001). In a seminal study that advanced the concept of role ambiguity in team cohesiveness, Kahn et al. (1964) created a theoretical model through which role ambiguity was measured as a multidimensional construct. In their study, the objectives included: 1) exploring the nature of role conflict and role ambiguity in industrial positions, 2) identifying work situations or contexts which intensify role ambiguity, 3) identifying the associations between situations or context and role ambiguity, as well as how individuals adjust, and 4) exploring how the effects of role ambiguity might be moderated by individual characteristics. Role ambiguity occurs when there are more number of supervisors on single employee or if there are different standards and demands regarding one particular job. Role ambiguity can cause employees dissatisfaction and thus, decreased his organizational commitment and ultimately results in low job performance (Shenkar, 1992). Rizzo et al., described role ambiguity as the inharmoniousness of the organizational demands from an employee in the reference of his role.

According to the theoretical model developed in this study, those dimensions include: 1) organizational factors, 2) personality factors, and 3) interpersonal factors. For organizational factors, role requirements were measured in three areas. First, the role was measured in terms of the extent to which the position crossed outside of the organization's boundaries or interacted with individuals outside of the organization. The researchers hypothesized that employees who work close to a boundary - both of the organization or of a department or work area - experience increased conflict about their role and increased tension. Second, the extent to which an employee's role requires innovative problem-solving for non-routine problems were measured. There is a tendency for organizations to select individuals with high self-confidence, high levels of career aspirations, and high engagement in the position for jobs with high requirements for innovative problem solving. Third, the role was measured for the extent to which the position was responsible for the work products of others. The study found that the highest levels of conflict regarding role in a job were in the upper/middle level of management, rather than at the lower levels of management.

Employees who do not get their part of duty and feel problem to understand the instruction and it makes them confuse about their job description often dissatisfied with their job. And there is a high probability for such employees to leave the organization or not become the active part in achieving various organizational goals. Role ambiguity can be a cause of the failure of an employee to show the productivity at workplace and can also be the failure of an organization in the long run (Beard, 1999).

The relationship of job satisfaction and the role ambiguity is of core importance which actually affects the employees' performance (McLaughlin, 2008). Many studies show a significant relation of role ambiguity and employee's satisfaction. Some studies have also been done on the universities' employees to obtain the empirical results about the relationship of employees' job performance and role ambiguity and found the same results (O'Driscoll \& Beehr, 2000). Therefore, the fourth hypothesis can be specified as following:

$\mathrm{H}_{4}$ : Role ambiguity moderates the relationship of job satisfaction and the performance of employees working in public universities of KSA.

Correlation between leadership and employees performance is empirically proved in many studies but in the case of role ambiguity exists, it becomes even more crucial to understand the relation of leadership and employees' performance. Leadership is considered as the helping role of the management to facilitate the employees to achieve the high level goals and to make them more comfortable and loyal with the organization to increase their performance (Robbins \& Judge, 2007).

Existence of role ambiguity can be a trouble for an employee in the case of achieving a certain benchmark to perform well. Leadership than comes forward and eliminate the ambiguities in the mind of an employee and let them perform well (Abdullah \& Kassim, 2011). Therefore, the fifth hypothesis can be specified as following:

\section{$H_{5}$ : Firm category moderates the effect of IT training on IT utilization}

Usually organizations want the highly skilled employees to obtain more accurate results and to avoid mistakes at the workplace. This is also due to the changing requirement of innovation and more confidence in the changing situation of 
the current markets. Many organizations offer training programs to their employees at different levels to enhance their capabilities (Sekaran \& Bougie, 2009).

Role ambiguity confuses the employees to understand their role descriptions and job requirements. Workers with low understanding with their job requirements cannot perform well at work place. So, by proper and ongoing training sessions regarding their job description, job goals and other work place related ambiguities can be removed (Bougie, 2009). Therefore, the sixth hypothesis can be specified as following:

$H_{6}$ : Role ambiguity moderates the relationship of training and the performance of employees working in the public universities of $\mathrm{KSA}$

\section{Proposed Research Framework}

Based on a detailed review of the literature exposes that the effects of job satisfaction, leadership, and training on the employees' performance by taking role ambiguity as moderating variable are still inconsistent. To resolve this inconsistency, this study suggested the proposed framework which is developed in relation to the hypotheses of this study as shown in Figure 1.

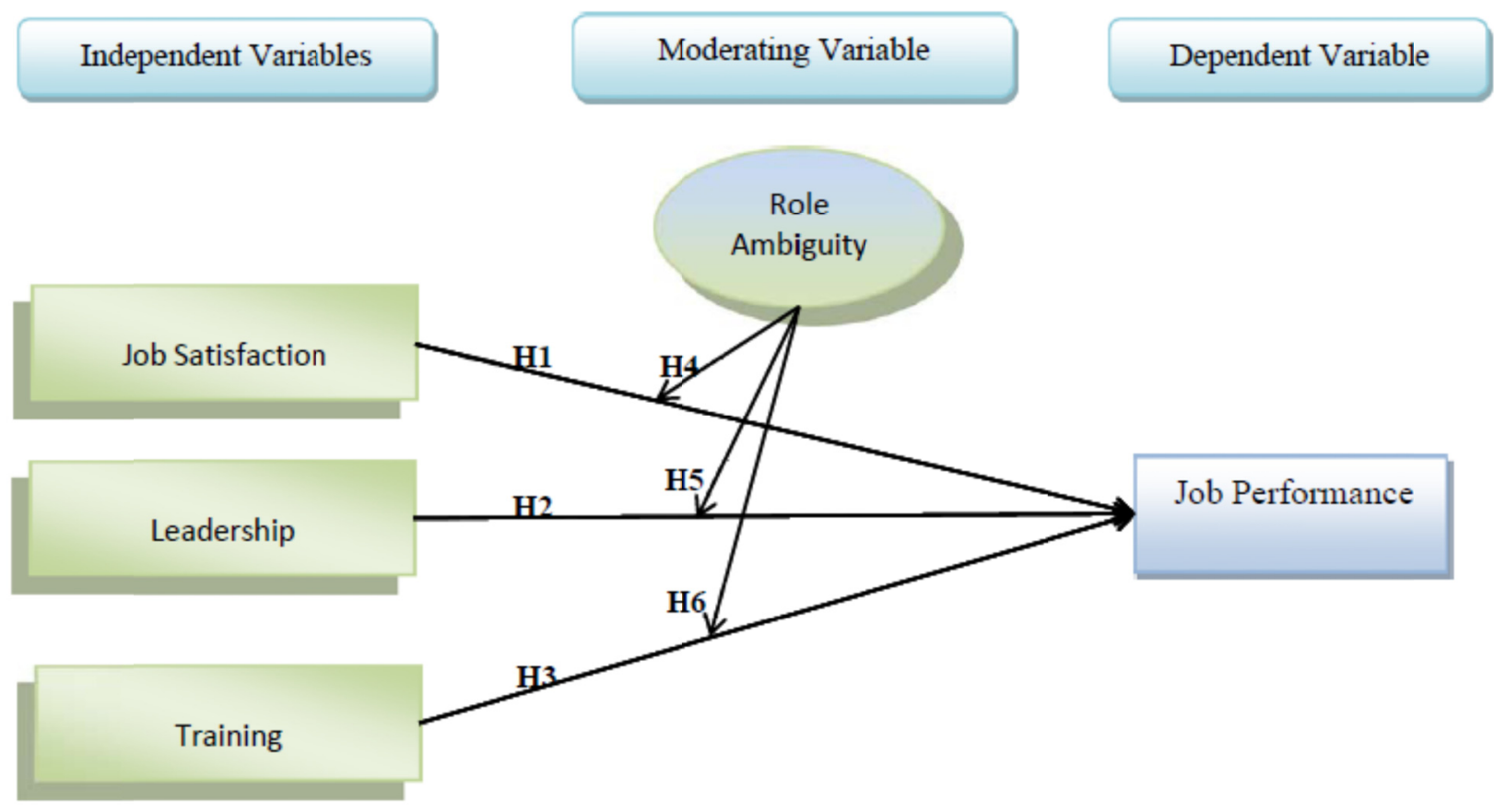

Figure 1. Research framework

\section{Discussion, and Future Research Directions}

In conclusion, this study tried to increase the borders of the knowledge refer to the implications of performance, job satisfaction, leadership, training and role ambiguity. The research model resulted from this study provides an original and unique theoretical framework which could be a reference model to examine the performance, job satisfaction, leadership, training and role ambiguity as moderating variable. The originality of this research framework could be due to the introduction of role ambiguity as moderating variable to explain the potential effect between job satisfaction, leadership, training and job performance. This framework was proposed to resolve the inconclusive results regarding the effects of role ambiguity on job performance.

In general, this research framework could be a guideline for future empirical research further explains the effect of job satisfaction, leadership, training and role ambiguity as moderating variable on employees' performance. The role ambiguity is of core importance variable which actually affects the employees' performance because role ambiguity can be a cause of the failure of an employee to show the productivity at workplace and can also be the failure of an organization in the long run.

To gain a deeper understanding on the role of ambiguity on the employees' performance in higher education, future studies are recommended to put forth some efforts to investigate the organizational culture and organizational commitment should be considered as an important variable in these causal relationships. Further studies could also 
examine the effect of some other influential variables on these relationships. In fact, the reality is very complex and in order for a researcher to have the clear picture, he has to take into account many other variables that might influence the proposed model.

\section{References}

Abdullah, F., Hamali, J., Deen, A.R., Saban, G., \& Abdurahman, A.Z.A. (2009). Developing a framework of success of Bumiputera entrepreneurs. Journal of Enterprising Communities: People and Places in the Global Economy, $3(1), 8-24$.

Abdullah, J. B., \& Md Kassim J. (2011). Instructional leadership and attitude towards organizational change among secondary schools principal in Pahang, Malaysia. Procedia - Social and Behavioral Sciences, 15, 3304-3309

Ahmed, I., et al. (2010). Effects of motivational factors on employees' job satisfaction a case study of University of the Punjab, Pakistan. International Journal of Business and Management, 5(3), 70-80.

Al-Kahtani, A. S. (2002). Organizational loyalty of Saudi employees in Saudi organizations.Global Competitiveness. Retrieved from http://www.allbusiness.com/marketing/market-research/332883-1.html

Altrasi, M. A. (2014). Determinants of Performance among Public Sector Managers in Saudi Arabia: An analysis of the organizational factors and job attitudes. Middle-East Journal of Scientific Research, 22(3).

Anonymous. (1998). Studying of relationship between emotional intelligence and employees performance: case study Bandar Abbas customs in Iran. Shahed University.

Armstrong, M. (2009). Armstrong Handbook of Human Resource Management Practice (1 $11^{\text {th }}$ ed.). Kogun Page.

Avolio, B. (1999). Full leadership development: building the vital forces in organizations. Sage Publications, Thousand Oaks, CA.

Awang, Z., Ahmad, J. H., \& Zin, N. M. (2010). Modelling job satisfaction and work commitment among lecturers: A case of UiTM Kelantan. Journal of StatisticalModeling and Analytics, 1(2), 45-59.

Bass, B. M. (1985). Leadership and Performance beyond Expectations. Free Press.

Beard, F. K. (1999). Client role ambiguity and satisfaction in client-ad agency relationships. Journal of Advertising Research, 39(2), 69-78.

Bernardin \& Rusel. (2006). Pinter Manajer, Aneka Pandangan Kontemporer. Alih Bahasa Agus Maulana. Penerbit Binarupa Aksara. Jakarta.

Bhuian, S.N., Menguc, B., \& Borsboom, R. (2005). Stressors and job outcomes in sales: a triphasic model versus a linear-quadratic-interactive model. Journal of Business Research, 58, 141-50.

Bohlander, G., Snell, S., \& Sherman, A. (2001). Managing human resources. Australia: South-Western College Publishing.

Borman, W. C., \& Motowidlo, S. J. (1993). Expanding the criterion domain to include elements of contextual performance. In N. Schmitt, \& W. C. Borman (Eds.), Personnel selection in organizations (pp. 71-98). San Francisco: Jossey-Bass.

Bougie, E. (2009). Aboriginal peoples survey, 2006: school experiences of off-reserve first nations children aged 6 to 14. Statistics Canada catalogue no. 89-637-X -No. 001. Ottawa; Statistics Canada, Social and Aboriginal Statistics Division, 2009. Retrieved $21 \quad$ September 2009, from http//dsp-psd.pwgsc.gc.ca/collection_2009/statcan/89-637-X/89-637-x2009001-eng-pdf

Campbell, J. P. (1990). Modeling the performance prediction problem in industrial and organisational psychology. In M. D. Dunnette \& L. M. Hough (Eds.), Handbook of industrial and organisational psychology (Vol. 1, pp. 687-732). Palo Alto: Consulting Psychologists Press.

Campbell, J. P. (1999). The definition and measurement of performance in the new age. In D. R. Ilgen \& E. D. Pulakos (Eds.), The changing nature of performance: Implications for staffing, motivation, and development (pp. 399-429).

Campbell, J. P., Gasser, M. B., \& Oswald, F. L. (1996). The substantive nature of job performance variability. In K. R. Murphy (Ed.), Individual differences and behaviour in organisations (pp. 258-299). 
Conway, A. R. A., Kane, M. J., \& Engle, R. W. (1999). Is Spearman's G determined by speed or working memory capacity? [Review of the book The G factor: The science of mental ability]. Psycoloquy, 10(74). Retrieved from http://psycprints.ecs.soton.ac.uk/archive/00000709/

David, Y., Syed, S., Zaini, A., \& Nilufar, A. (2009). A Study of Job Stress on Job Satisfaction among University Staff in Malaysia: Empirical Study. European Journal of Social Sciences, 8(1), 121-129.

Dessler, G. (2011). Human Resource Management (12th ed.). Prentice-Hall, USA.

Elnaga, A. (2013). The Effect of Training on Employee Performance. European Journal of Business and Management.

Eys, \& Carron. (2001). The dynamic relationship between job satisfaction and job performance. (Doctoral dissertation). Retrieved from ProQuest Dissertations and Theses database. (AAT9938300).

Eysenck, M. (1998). Psychology: An integrated approach. New York: Addison-Wesley Longman. European Industrial Training, 8(4), 25-32.

Fiorita, J. A., Bozeman, D. P., Young, A., \& Meurs, J. A. (2007). Organization commitment, human resource practices, and organization characteristic. Journal of Managerial Issues, 19(2), 186-207

Fisher, C. D. (2001). Why do lay people believe that satisfaction and performance are correlated? Possible sources of a Goleman, D. 2001-2003. Working with emotional intelligence. Bantam Books.

Hakeern, A. M. B. Almarganhi. (2008). The Relationship between Motivation and Job Satisfaction on Employee's Performance in Universiti Utara Malaysia. Working Paper.

Hashim, J. (2008). Competencies acquisition through self-directed learning among Malaysian managers. Journal of Workplace Learning, 20(4), 259-271.

Higher Education. (2006). The TQM Magazine, 18(5), 484-500.

Hulin, C. L., \& Judge, T. A. (2003). Job attitudes: A theoretical and empirical review. In W.C.Borman, D. R. Ilgen, \& R. J. Klimoski (Eds.), Handbook of psychology (Vol. 12, pp. 255-276). Hoboken, NJ: Wiley.

Icondalkar. (2007). The job evaluation handbook. London: Institute of Personnel Development.

Jehn, K.A. A. (1997). Qualitative Analysis of Conflict Types and Dimensions in Organizational Groups. Administrative Science Quarterly, 42(3), 530-557.

Jex, S. M., \& Britt, T. W. (2008). Organisational Psychology - A Scientist-Practioner Approach. New Jersey: John Wiley \& Sons.

Kahn, R. L., Wolfe, D. M., Quinn, R. P., Snoek, J. D., \& Rosenthal, R. A. (1964). Occupational stress: Studies in role conflict and ambiguity. New York: John Wiley.

Kassim, Zorah Abu, \& Sulaiman, Mohamed. (2011). Market Orientation And Leadership Styles Of Managers in Malaysia. International Journal of Leadership Studies, 6(2), 2011.

Khalid, S., Isrhad, M.Z., \& Mahmood, B. (2012). Job Satisfaction among Academic Staff: A Comparative Analysis between Public and Private Sector Universities of Punjab, Pakistan. International Journal of Business and Management, 7(1), 126-136.

Kinicki \& Kreitner. (2007). A theory of reasoned action: applications and implications. In H. Howe, \& M. Page (Eds.), Nebrasca Symposium on Motivation (pp. 65-116). Lincoln: University of Nebraska.

Kondalkar, V.G. (2007). Organizational Behaviour. New Age International (P) Ltd., Publishers.

Koontz, H., \& Donnell, C. (1993). Introduction to Management. McGraw-Hill Inc., New York.

Koontz, H., \& O'Donnell, C. (1976). Management: A systems and contingency analysis of managerial functions (6th ed.). New York: McGraw-Hill.

Lado, A. A., Boyd, N. G., \& Wright, P. (1992). A Competency-based Model of Sustainable Competitive Advantage: Toward a Conceptual Integration. Journal of Management, 18(1), 77-91.

Landy. (1978). Is entrepreneurial competency and business success relationship contingent upon business environment?A study of Malaysian SMEs. International Journal of Entrepreneurial Behaviour\& Research, 16(3), 182-203.

Landy, F. J. (1985). Psychology of Work Behavior. Homewood, IL: Dorsey Press. 
Lang, J., Thomas, J.L., Bliese, P.D., \& Adler, A.B. (2007). Job demands and job performance: the mediating effect of psychological and physical strain and the moderating effect of role clarity. Journal of Occupational Health Psychology, 12(2), 116-124.

Lee, Hsien-Che, \& Chuang, Tsai-hua. (2009). The Impact of Leadership Styles on Job Stress and Turnover Intention: Taiwan Insurance Industry as an Example. Thesis for Master of Business Administration, Tatung University.

Lu, J.F., Tjosvold, D., \& Kan Shi. (2010). Team Training in China: Testing and Applying the Theory of Cooperation and Competition. Journal of Applied Social Psychology, 40(1), 101-134.

Mackin, D. (2006). Emotional intelligence. New Directions Consulting, Inc.

Mathis, R. L., \& Jackson, J. H. (2000). Human resource management. Australia: South-Western: College Publishing.

Mayer, J.D., \& Cobb, C.D. (2000). Educational Policy on Emotional Intelligence: Does It Make Sense? Educational Psychology Review, 12(2).

McGrath, R. M., \& MacMillan, I. C. (2000). The entrepreneurial mindset. Boston: Harvard Business School Press.

McLaughlin, K., Moutray, M., \& Muldoon, O. T. (2008). The role of personality and self-efficacy in the selection and retention of successful nursing students: A longitudinal study. Journal of Advanced Nursing, 67, 211-221.

McShane, S. L., \& Von Glinow, M. A. (2010). Organisationalbehaviour-emerging knowledge and practice for the real world (5th ed.). NY: McGraw-Hill Irwin.

Murphy, K. J., Baker, G., \& Gibbons, R. (1994). Subjective Performance Measures in Optimal Incentive Contracts. Quarterly Journal of Economics, 109, 1125-1156.

Nanthini, M. (2007). Antecedents and impact of psychological ownership among academicians in business faculties of Malaysian public universities. Unpublished Master of Science Thesis. UPM. Serdang.

O'Driscoll, M. P., \& Beehr, T. A. (2000). Moderating effects of perceived control and need for clarity on the relationship between role stressors and employee affective reactions. Journal of Social Psychology, 140(2), 151-9.

Potluri, R. M., \& Zeleke, A.A. (2009). Evaluation of customer handling competencies of Ethiopian employees. African Journal of Business Management, 3(4), 131-135.

Robbins, S. P., \& Judge, T. (2007). Organizational behavior. Upper Saddle River, N.J: Pearson/Prentice Hall.

Robbins, S. P., \& Judge, T. A. (2009). Organizational Behavior. Contemporary Issues in Leadership, 13, 425-455.

Robbins, S. P., Judge, T.A., Millett, B., \& Waters-Marsh, T. (2008). Organisational Behaviour (5th ed.). Pearson Education, Fenchs Forest, NSW.

Roshidi, Hassan. (2005). Perceptions of academicians towards performance appraisal in a Malaysian public university. Unpublished PhD Thesis. School of Graduate Studies UPM. Serdang.

Rowe, W. G. (2001). Creating Wealth in Organizations: The Role of Strategic Leadership. Academy of Management Executive, 15, 81-94.

Salmani, Taatian. (2010). Survey of leadership styles in different cultures. Iranian Journal of Management Studies (IJMS), 3(3), 91- 111.

Santora, J. C., Seaton, W., \& Sarros, J. C. (1999). Changing Times: Entrepreneurial Leadership in a Community-based Nonprofit Organization. Journal of Leadership Studies, 6(3-4), 101- 109.

Sekaran, U., \& Bougie, R. (2009). Research Methods for Business: A Skill Building Approach (5th ed.). John Wiley \& Sons Ltd., United Kingdom.

Shahzad, K., Sarmad M., Abbas, M., \& Khan, M. A. (2011). Impact of Emotional Intelligence (EI) on employee's performance in telecom sector of Pakistan. African Journal of Business Management, 5(4), 1225-1231.

Shenkar, O., \& Zeira, Y. (1992). Role conflict and role ambiguity of chief executive officers in international joint ventures. Journal of International Business Studies, 23(1), 55-75.

Stogdill, M., \& Coons, A. (1957). Leader Behavior: Its Description and Measurement. Research Monograph no 88, Columbus, OH: Bureau of Business Research Ohio State University.

Tai. (2006). Skill-based technological change and wage inequality: evidence from a plant retooling. The American Journal of Sociology, 107, 273-320. 
Tai, W. T. (2006). Effects of Training Framing, General Self-efficacy and Training Motivation on Trainees' Training Effectiveness. Personnel Review, Emerald Group Publishers, 35(1), 51-65.

Teece, D. J., Pisano, G., \& Shuen, A. (1997). Dynamic Capabilities and Strategic Management. Strategic Management Journal, 18(7), 509-533. http://dx.doi.org/10.1002/(SICI)1097-0266(199708)18:7<509::AID-SMJ882>3.0.CO;2-Z

Vakola, M., Soderquist, K.E., \& Prastacos, G.P. (2007). Competency management in support of organisational change. International Journal of Manpower, 28(3/4), 260-275.

Venkataraman, S. (1997). The distinctive domain of entrepreneurship research: An editor's perspective. In Jerome Katz and R. Brockhaus (Eds.), Advances in Entrepreneurship, Firm Emergence, and Growth (Vol. 3, pp.119-138). Greenwich, CT: JAI Press.

Vichita Vathanophas, \& Jintawee Thai-ngam. (2007, March). Competency requirements for effective job performance in the Thai public sector. Contemporary Management Research, 3(1), 45-70.

Winarno, J. (2008). Emotional intelligence sebagai salah satu factor Penunjang Prestasi Kerja. Jurnal Manajement, $8(1), 14-17$.

Wu, W.S., Li, W.H., \& Chen, B.S. (2007). Identifying regulatory targets of cell cycle transcription factors using gene expression and ChIP-chip data. BMC Bioinformatics, 8:188.

Yang. (2010). Modes of theorizing in strategic human resource management: Tests of universalistic, contingency, and configurational performance predictions. Academy of Management Journal, 39, 802-835.

Yukl, G. (1989). Managerial Leadership: a review of theory and research. Journal of Management, 15(2), 251-290

Zaccaro, S. J., \& Klimoski, R. J. (2002). The nature of organizational leadership: An introduction. In S. J. Zaccaro \& R. J. Klimoski (Eds.), The nature of organizational leadership (pp. 3-41). San Francisco, CA: Jossey-Bass. 